\title{
ПИРРОЛИДОНКАРБОКСИЛАТЫ \\ КАК ЭФФЕКТИВНЫЕ ПРЕКУРСОРЫ В СИНТЕЗЕ ЗАМЕЩЕННЫХ ГАМК, ГЛУ И 2-ПИРРОЛИДОНА
}

\author{
С.В. Макаренко', И.Н. Тюренков², О.С. Васильева', Е.С. Остроглядов ${ }^{1}$ \\ ${ }^{1}$ Российский государственный педагогический университет им. А.И.Герцена, \\ 191186, Санкт-Петербург, наб. р. Мойки, д. 48. E-mail: kohrgpu@yandex.ru. \\ ${ }^{2}$ Волгоградский государственный медицинский университет, \\ 400131, Волгоград, пл. Павших Борцов, д. 1.
}

DOI: 10.19163/MedChemRussia2021-2021-26

E-mail:vlgmed@avtlg.ru

Модификация структур молекул генетически связанных между собой нейромедиаторов центральной нервной системы животных и человека $\gamma$-аминомасляной (ГАМК), глутаминовой (Глу) кислот и $\alpha$-пирролидона является перспективным направлением целенаправленного синтеза новых фармакологически активных веществ-субстанций. Эффективными прекурсорами в синтезе веществ, содержащих фрагменты этих структур, являются эфиры замещённых 2-пирролидон-3(5)-карбоновых и -1-уксусных кислот (I).<smiles></smiles>

Нами разработаны способы получения эфиров 4(5)-гетарилзамещённых 2-пирролидон-3(5)-карбоновых, -3,5,5-трикарбоновых и -1-уксусных кислот (I), в структуре молекул которых присутствуют при атоме азота алкоксикарбонилалкильный (или ацетильный) заместители или нитроэтильный фрагмент при атоме C(3). На их основе синтезированы значительные ряды аналогов ГАМК (II), Глу (III), 2-пирролидона (IV), в том числе, и замещённых 3,3'-спироби[2-пирролидона] (V). Последние являются оригинальными прекурсорами в синтезе ранее неизвестных спироаналогов пирацетама (VI), N-карбоксиэтил- (VII) и 2-аминоэтилГАМК (VIII), содержащих различные фармакофорные группы. Фармакологические свойства наиболее перспективных веществ защищены патентами. 